\title{
Research
}

\section{Biophysical and Socioeconomic Factors Associated with Forest Transitions at Multiple Spatial and Temporal Scales}

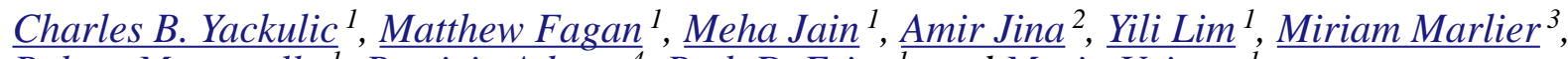 \\ $\underline{\text { Robert Muscarella }}^{1}, \underline{\text { Patricia Adame }}^{4}, \underline{\text { Ruth DeFries }}^{1}$, and Maria Uriarte $^{1}$
}

\begin{abstract}
Forest transitions (FT) occur when socioeconomic development leads to a shift from net deforestation to reforestation; these dynamics have been observed in multiple countries across the globe, including the island of Puerto Rico in the Caribbean. Starting in the 1950s, Puerto Rico transitioned from an agrarian to a manufacturing and service economy reliant on food imports, leading to extensive reforestation. In recent years, however, net reforestation has leveled off. Here we examine the drivers of forest transition in Puerto Rico from 1977 to 2000 at two subnational, nested spatial scales (municipality and barrio) and over two time periods (1977-1991 and 1991-2000). This study builds on previous work by considering the social and biophysical factors that influence both reforestation and deforestation at multiple spatial and temporal scales. By doing so within one analysis, this study offers a comprehensive understanding of the relative importance of various social and biophysical factors for forest transitions and the scales at which they are manifest. Biophysical factors considered in these analyses included slope, soil quality, and land-cover in the surrounding landscape. We also considered per capita income, population density, and the extent of protected areas as potential factors associated with forest change. Our results show that, in the 1977-1991 period, biophysical factors that exhibit variation at municipality scales $(\sim 100$ $\mathrm{km}^{2}$ ) were more important predictors of forest change than socioeconomic factors. In this period, forest dynamics were driven primarily by abandonment of less productive, steep agricultural land in the western, central part of the island. These factors had less predictive power at the smaller barrio scale $\left(\sim 10 \mathrm{~km}^{2}\right)$ relative to the larger municipality scale during this time period. The relative importance of socioeconomic variables for deforestation, however, increased over time as development pressures on available land increased. From 1991-2000, changes in forest cover reflected influences from multiple factors, including increasing population densities, land development pressure from suburbanization, and the presence of protected areas. In contrast to the 1977-1991 period, drivers of deforestation and reforestation over this second interval were similar for the two spatial scales of analyses. Generally, our results suggest that although broader socioeconomic changes in a given region may drive the demand for land, biophysical factors ultimately mediate where development occurs. Although economic development may initially result in reforestation due to rural to urban migration and the abandonment of agricultural lands, increased economic development may lead to deforestation through increased suburbanization pressures.
\end{abstract}

Key Words: agricultural abandonment; deforestation; forest transition; Puerto Rico; reforestation

\section{INTRODUCTION}

Over the past two centuries, population growth, urbanization, and industrialization have induced a prolonged decline and then a partial recovery in the extent of forest cover in many regions across the globe (Mather 1992, Rudel et al. 2005). Mather
(1992) argued that this pattern of forest change is related to a nation's social and economic development: as a nation develops economically, forest cover typically declines. With increasing development, however, this loss may halt and actually reverse, leading to an increase in the extent of forest cover. The point of inflection in this 
transition occurs when the rate of reforestation exceeds that of deforestation, a phenomenon described as the forest transition (FT).

Since its inception, FT theory has focused on understanding the factors that lead to these transitions. Net increases in forest cover have been associated with a number of social, economic, and biophysical factors such as the development of industry, increased agricultural efficiency and abandonment of unproductive agricultural lands (Mather 1992, Mather and Needle 1998, Perz and Skole 2003, Rudel et al. 2009), international trade, urban migration, changes in sources of energy (DeFries et al. 2010), and overall economic development (Mather et al. 1999, Southworth and Tucker 2001, Grau and Aide 2008). The enumeration of these drivers, however, leaves unanswered how important these social and biophysical factors are relative to one another and how they interact to induce land cover change at different spatial and temporal scales (Rudel et al. 2005).

Spatially, data constraints have largely restricted the study of FT to the national scale, ignoring possible consequences of a nation's forest transition on larger, e.g., regional or global, and smaller, e.g., subnational, spatial scales (Hecht et al. 2006, Perz 2007, Meyfroidt and Lambin 2009). Many forest transitions may not reflect net gains in global forest cover, but rather an offshoring of agricultural demand that causes compensatory deforestation in other countries or regions (Meyfroidt and Lambin 2009, DeFries et al. 2010, Pfaff and Walker 2010). Similarly, examining national-scale trends can mask important variation at a subnational level. At this smaller scale, patterns of forest change may be better described by the opportunity costs of maintaining forest cover or converting the land to an alternate, more profitable use (Barbier et al. 2010). Biophysical factors such as topography, soil fertility and slope may lead to concentration of agriculture on flatter and more fertile lands, allowing reforestation of marginal, abandoned agricultural areas (Rudel et al. 2000, Wright and Samaniego 2008, Crk et al. 2009). Socioeconomic variables, such as urban-rural migration or the connectivity of the land to urban centers, may reduce the probability of reforestation by increasing relative land value (MacDonald and Rudel 2005, Crk et al. 2009). Forest cover change may also be mediated by external factors, such as technological advances, market forces, government policies, and institutional factors (Izquierdo et al. 2008, Barbier et al. 2010).

Temporally, FT theory describes a long-term, historical dynamic process but many empirical studies are restricted to a single time period (e.g., Rudel et al. 2000, Thomlinson and Rivera 2000). However, biophysical and socioeconomic factors associated with forest change may vary temporally because of shifting policies or changes in external influences on land values (Barbier et al. 2010, DeFries et al. 2010). Furthermore, as socioeconomic development proceeds and societies transition from rural to urban environments, forest regeneration may level off, in some cases reverting to net deforestation from suburbanization pressures (Thomlinson and Rivera 2000, McDonald and Rudel 2005, Irwin and Bockstael 2007). Examining forest transitions over longer time scales or across multiple periods would determine whether predictors of forest change remain constant through time.

Finally, the emphasis of FT theory on net forest change ignores the fact that reforestation and deforestation are different processes that may respond to distinct factors (Rudel et al. 2005, Lambin and Geist 2006, Meyfroidt and Lambin, 2009). Proximate causes of deforestation include infrastructure development, agriculture expansion, and wood extraction, which are in turn driven by ultimate economic, technological, political, and cultural factors (Lambin and Geist 2006). Although abandonment of agricultural land is often seen as a prerequisite for secondary forest regrowth, the proximate and ultimate drivers for reforestation may be as diverse as those of deforestation, including wood shortages, changes in fire regime with increased population density, and insecure land tenure. The common aggregation of reforestation and deforestation into net forest change makes it unclear whether the factors that favor deforestation will simultaneously hinder reforestation. By separately examining patterns of deforestation and reforestation, we can illuminate the potentially different predictors of these two processes.

The forest transition and related phenomena have been extensively studied on the Caribbean island of Puerto Rico from both a socioeconomic (Rudel et al. 2000) and a forest dynamics perspective (Aide et al. 2000, Grau et al. 2003). Economic decisions 
at the end of the Second World War and a special relationship with the U.S. led to fast-paced economic development in Puerto Rico that changed an agrarian economy to one based on light industrial activities (Weisskoff and Wolff 1977, Dietz 1986, Rudel et al. 2000), drawing laborers to the cities and to the mainland U.S. The integration of households into the global economy via labor migration and remittances led to an initial wave of forest recovery, which was sustained until the 1990s. Forest cover in Puerto Rico increased from less than $20 \%$ in 1951 to about $57 \%$ today (Brandeis et al. 2007). Population increased from 2 to 3.9 million over this time period (Grau et al. 2003). Lately, the increase in forest cover has decelerated and even reversed at some scales (Martinuzzi et al. 2007). Given these drastic changes in forest cover over a prolonged period, Puerto Rico is an ideal location to examine the social and biophysical drivers of forest change through time.

Previous studies offer some insight as to which factors may be driving land use and land cover change (LUCC) in Puerto Rico. Reforestation has been associated with outmigration, decreases in agricultural production, protected area status, and proximity to forest patches (Rudel et al. 2000, Helmer et al. 2008, Crk et al. 2009). The major drivers of deforestation appear to be rising household incomes and material consumption, development of suburbs, and household sorting behavior across neighborhoods within major metropolitan areas (Parés-Ramos et al. 2008, Martinuzzi et al. 2007). Despite this extensive work on the FT in Puerto Rico, previous studies have typically emphasized individual aspects of the FT, e.g., social or biophysical factors, focused on particular spatial scales, e.g., pixel, county, or island, and considered net reforestation or deforestation only (Rudel et al. 2000, Grau et al. 2003, Martinuzzi et al. 2007, Helmer et al. 2008, Parés-Ramos et al. 2008). This study builds on previous work by simultaneously considering the social and biophysical factors previously found to drive forest transitions within one study, by considering these same drivers of forest change at multiple spatial and temporal scales, and by examining how these drivers influence reforestation and deforestation separately. By examining all of these components within one analysis, this study offers a comprehensive understanding of the relative importance of various social and biophysical factors for forest transitions at multiple scales in Puerto Rico.

We accomplish these goals by fitting hierarchical models for each process (reforestation and deforestation) and time period (1977-1991 and 1991-2000) separately and comparing the standardized coefficients associated with each predictor in the four resulting models. To understand the spatial scale at which these factors act, we use predictors and forest change data measured at the submunicipality (barrio) scale and include random effects at the municipality scale. Through the use of multilevel $\mathrm{R}^{2}$ we are then able to explore the degree to which individual predictors explain variance in forest change at the municipality and submunicipality scales. Our hypotheses for the effects of specific predictors on deforestation and reforestation are summarized in Table 1.

\section{METHODS}

\section{Study site}

Puerto Rico is the easternmost island of the Greater Antilles, measuring $160 \mathrm{~km} \mathrm{E-W}$ and $55 \mathrm{~km} \mathrm{N-S}$. Annual precipitation varies across the island from approximately $1500-2000 \mathrm{~mm}$ in the northeast mountains (900-1100 meters) to approximately 750 $\mathrm{mm}$ on the south coast. Mean annual temperatures range between 19.4 and $29.7^{\circ} \mathrm{C}$ with cooler temperatures occurring at higher elevations (Daly et al. 2003). The steep climate gradient, large elevation range, and a complex geology have generated striking environmental variation within the island. Vegetation ranges from dry, semideciduous forests in the southwest part of the island, to moist forests throughout most of the island and rain forests at higher elevations (Daly et al. 2003).

In this study we investigate forest transition at both the municipality and barrio (submunicipality) scales. Puerto Rico is comprised of 78 municipios (municipalities range from 13.2 to $328.9 \mathrm{~km}^{2}$ ) that are further subdivided into approximately 875 barrios (submunicipalities range from 0.12 to 64.13 $\mathrm{km}^{2}$ ). These two scales represent the legal and political subdivisions of Puerto Rico. Zoning laws are defined at the municipality level but these laws are poorly implemented and regulated (Dietz 1986, 
Table 1. Explanatory variables and associated hypotheses for analyses of forest change in Puerto Rico.

\begin{tabular}{|c|c|c|c|}
\hline Explanatory Variables & Data Source & $\begin{array}{l}\text { Hypothesized } \\
\text { Relationship }\end{array}$ & Rationale \\
\hline \multicolumn{4}{|l|}{ Socioeconomic } \\
\hline $\begin{array}{l}\text { Population density } \\
(1980,1990)\end{array}$ & U.S. Census & $\begin{array}{l}+ \text { Defor } \\
\text { - Refor }\end{array}$ & $\begin{array}{l}\text { Higher population density will be associated with } \\
\text { greater land use intensity. }\end{array}$ \\
\hline $\begin{array}{l}\text { Population density change } \\
(1980-1990,1990-2000)\end{array}$ & U.S. Census & $\begin{array}{l}+ \text { Defor } \\
\text { - Refor }\end{array}$ & $\begin{array}{l}\text { Urban-rural migration may drive deforestation for } \\
\text { suburban development (MacDonald and Rudel 2005). }\end{array}$ \\
\hline $\begin{array}{l}\text { Normalized per capita income } \\
\left(1980^{\dagger}, 1990\right)\end{array}$ & U.S. Census & $\begin{array}{l}+ \text { Defor } \\
\text { - Refor }\end{array}$ & $\begin{array}{l}\text { Rising local incomes may be associated with higher } \\
\text { local land use intensity and suburbanization (Margo } \\
\text { 1992). }\end{array}$ \\
\hline $\begin{array}{l}\text { Normalized income change } \\
\left(1980-1990^{\dagger}, 1990-2000\right)\end{array}$ & U.S. Census & $\begin{array}{l}+ \text { Defor } \\
\text { - Refor }\end{array}$ & $\begin{array}{l}\text { Short-term increases in local income may reflect } \\
\text { suburban development (Parés-Ramos et al. 2008). }\end{array}$ \\
\hline $\begin{array}{l}\text { Percent of area in reserve/protected } \\
\text { area }\end{array}$ & $\begin{array}{l}\text { GAP (Gould et } \\
\text { al. 2007) }\end{array}$ & $\begin{array}{l}\text { - Defor } \\
+ \text { + Refor }\end{array}$ & $\begin{array}{l}\text { Protected areas can deter forest cover change (Helmer } \\
\text { 2004). }\end{array}$ \\
\hline \multicolumn{4}{|l|}{ Biophysical } \\
\hline Life zones & USGS (2009) & $\begin{array}{l}\text { w/ } \uparrow \text { Moisture } \\
\quad \text { - Defor } \\
\quad+\text { Refor }\end{array}$ & $\begin{array}{l}\text { Precipitation is likely to affect vegetation dynamics and } \\
\text { favor regrowth (Daly et al. 2003) or alternatively, } \\
\text { reforestation may be slower in drier areas because of } \\
\text { fires (Brandeis et al. 2007). }\end{array}$ \\
\hline Median slope & USGS (2009) & $\begin{array}{l}\text { - Defor } \\
+ \text { Refor }\end{array}$ & $\begin{array}{l}\text { Slope affects development and agricultural cost (Turner } \\
\text { et al. 2009, Crk et al. 2009). }\end{array}$ \\
\hline $\begin{array}{l}\text { Median soil agricultural capacity ( } 1 \text { is } \\
\text { most fertile, } 10 \text { is least fertile) }\end{array}$ & $\begin{array}{l}\text { USGS NRCS } \\
(2007)\end{array}$ & $\begin{array}{l}+ \text { Defor } \\
\text { - Refor }\end{array}$ & $\begin{array}{l}\text { Marginal lands are often the first areas to reforest } \\
\text { because they are more likely to be abandoned than } \\
\text { areas with high quality soil (Mather and Needle 1998). }\end{array}$ \\
\hline $\begin{array}{l}\text { Total forest cover } \\
(1977,1991)\end{array}$ & $\begin{array}{l}\text { IITF/USDA } \\
\text { Forest Service }\end{array}$ & + Refor & $\begin{array}{l}\text { By facilitating seed dispersal to abandoned sites, the } \\
\text { extent and spatial distribution of forest cover can } \\
\text { influence the rate of forest recovery (Thomlinson et al. } \\
\text { 1996, Helmer et al. 2008, Crk. et al. 2009). }\end{array}$ \\
\hline
\end{tabular}

$\dagger$ Per capita income data for 1980 only available at the municipality scale.

IITF = International Institute of Tropical Forestry

Hunter and Arbona 1995). Because the majority of land in Puerto Rico is privately owned, developers and private land owners often make the decisions that result in land use/land cover change at the barrio level. Because we were primarily interested in reforestation and deforestation outside of citycenters, we used the 1977 land cover map to exclude 84 urban barrios that had greater than $50 \%$ urban land cover from our analysis. In addition, barrios with zero total forest cover or unavailable socioeconomic data were excluded (Fig. 1).

\section{Data collection}

\section{Land cover}

Three land cover GIS layers ("maps") were used to examine changes in land cover patterns over time. The earliest map was generated by manual interpretation of 1:20,000 scale aerial photographs from 1977 and 1978 and digitized to polygons by Ramos and Lugo (1994). We converted this map to raster at a lower, $30 \mathrm{~m}$ pixel scale resolution. The two other land cover maps were based on Landsat 
Fig. 1. Percentage forest cover in 1977, 1991, and 2000 land cover/use GIS layer calculated at the barrio (submunicipality) scale. Barrio boundaries are shown in white and municipio boundaries in black (See Appendix for data sources).
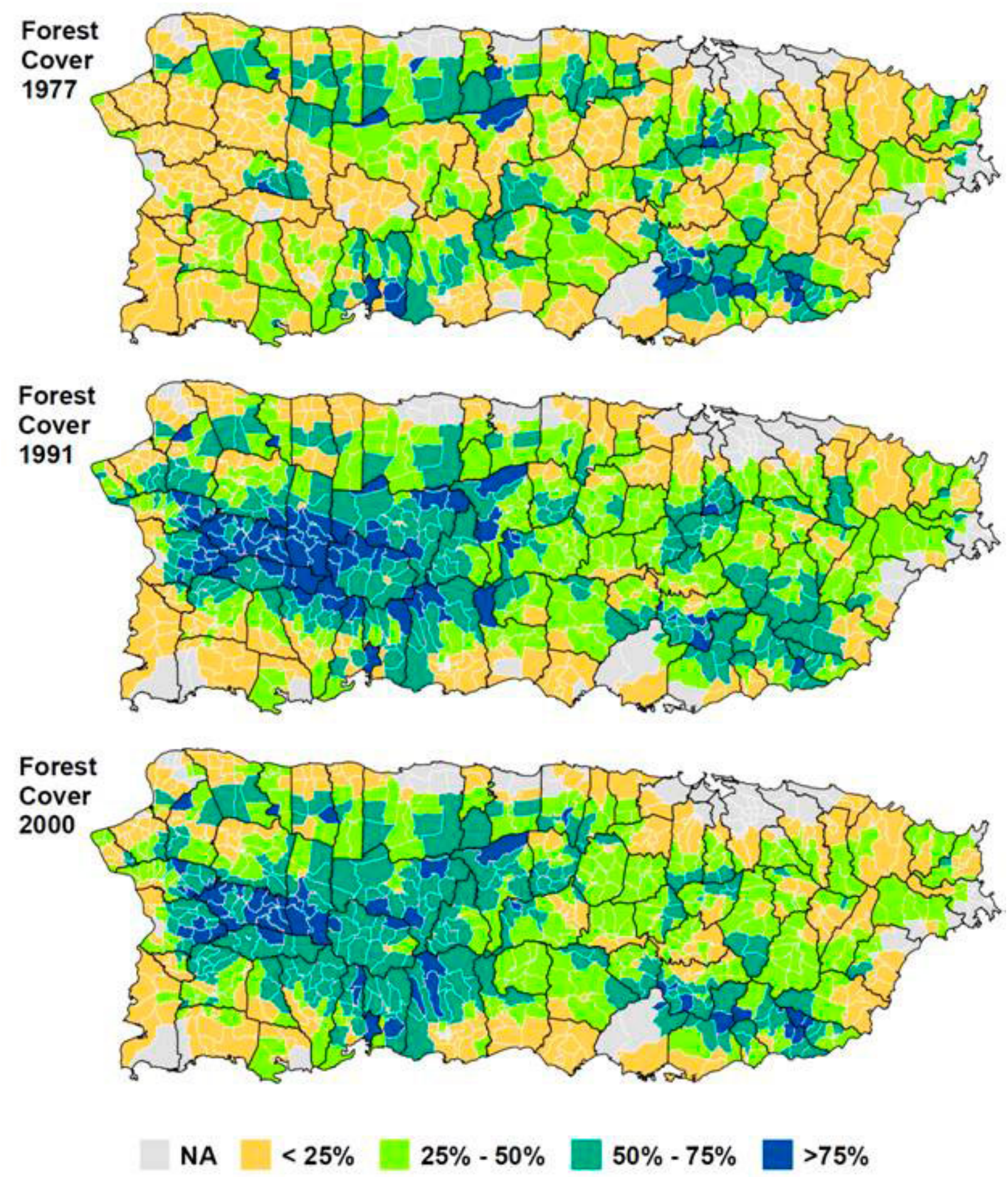
TM and ETM + mosaics of images taken ca 1991-1992 and 2000 with $30 \mathrm{~m}$ resolution (Kennaway and Helmer 2007). Details on land cover classification and accuracy are provided in Appendix 1.

\section{Biophysical predictors}

Biophysical characteristics can influence forest transition through their effects on land use patterns (Table 1). We used a 30 × 30 m Shuttle Radar Topography Mission digital elevation model (USGS 2009) to calculate median elevation and slope for each barrio. Elevation was not included in the analysis because it was highly correlated with slope at both spatial scales $(r=0.73$, both $p<0.001)$. We also used a categorical classification of land into dry, moist, and wet life zones (Daly et al. 2003).

To explore the effect of soil quality on forest transitions, we used a measurement of soil agricultural capacity that groups soils into 10 classes based on characteristics such as erosion and moisture retention potential, soil depth, and presence of toxic salts, with 1 being the most fertile and 10 being least fertile(USDA NRCS 2007; Table 1 ). We used the median agricultural capacity of each barrio for this analysis.

We included the percentage of forested area in each administrative unit at the beginning of each period as a predictor of reforestation. The total amount of forested area, however, was not included in the deforestation analyses because it was already implicit in our model; only areas that are forested can become deforested.

\section{Socioeconomic predictors}

Socioeconomic conditions can also influence patterns of land use change and forest transition (Table 1). In Puerto Rico, socioeconomic factors include rising incomes and substantial rural-urban migration. We extracted per capita income (in 2000 US\$) and total population from the 1980, 1990, and 2000 U.S. Decennial Census for each barrio.

To normalize for differences in area among administrative units, we converted total population into population density. We also normalized income for each administrative unit with respect to mean income across the island at each time period. Finally, we included change in population density and income in each time period. Because we were unable to obtain per capita income data for 1980 at the barrio scale, we used 1990 income data as a proxy because per capita income values were highly correlated among all years $(r>0.90, p<0.001)$, and omitted income change as a predictor in the 1977-1991 analysis.

Finally, we calculated total protected area in each barrio from the Puerto Rico Gap Analysis Project (Gould et al. 2007). We included the percentage of protected areas in each barrio as a predictor. Travel time to the nearest urban center $(>500$ ha in the 1977 map) was originally included but was dropped because preliminary analyses failed to show significance. Although many other socioeconomic variables are cited as important in the literature, for example, land value, land ownership, institutional variables, these data were not readily available for Puerto Rico.

\section{Statistical analyses}

For each period (1977-1991, 1991-2000) and transition type (reforestation or deforestation) we fit separate statistical models where the response variable was the number of pixels that became reforested or deforested in a barrio during the time period. The log of the number of potential pixels that could be reforested/deforested was included as an offset. We used the logarithm as the link function in our analysis and initially used a Poisson distribution. However, initial model residuals showed over-dispersion so the final results reported here are all based on negative binomial generalized linear mixed models with a log link.

For each separate period and transition type, we selected the best submodel based on Deviance Information Criterion (DIC; Spiegelhalter et al. 2002). Starting with the full model (Table 1), we compared it to the set of all submodels formed by dropping each one of the predictors independently. If the full model had the lowest DIC, we stopped; otherwise we selected the submodel with the best DIC and compared it to the set of models formed by dropping additional predictors.

To facilitate interpretation of effect magnitudes among covariates, all continuous predictors were standardized by subtracting their mean and dividing by twice their standard deviation. Life zone was 
Fig. 2. Barrio (submunicipality) scale reforestation and deforestation rates calculated for 1977-1991 and 1991-2000 time intervals. Barrio boundaries are shown in white and municipio boundaries in black.
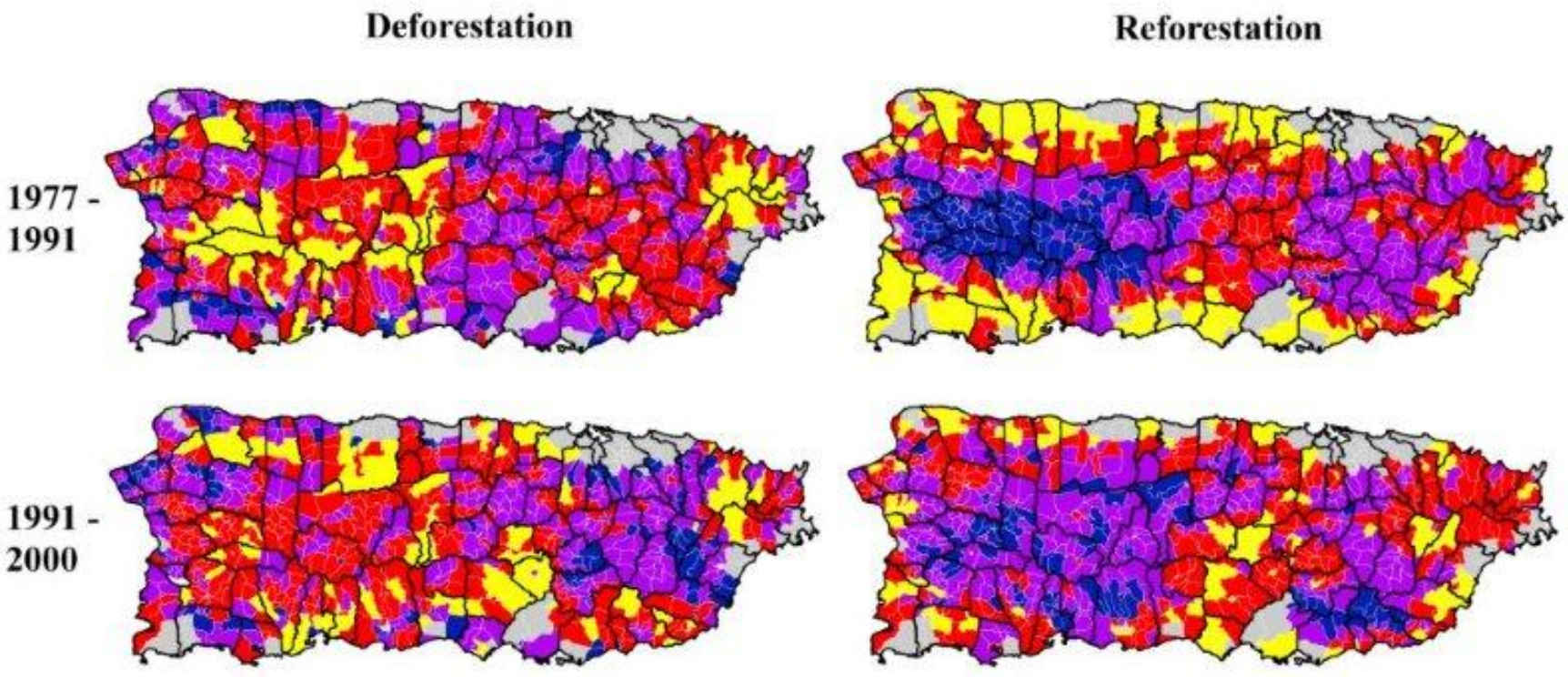

Annual rates

NA

$0 \%-1 \%$

$1 \%-2.5 \%$

$2.5 \%-5 \%$

$5 \%-10 \%$

treated as a categorical covariate. To ensure that parameter estimates between the two periods could be easily compared, the log of the number of years in the period was included as an offset. Coefficients for all other parameters were estimated using WinBugs with weakly or noninformative priors and models were judged to converge when r-hats for all parameters were \&\#8804 1.1 (Gelman and Rubin 1992).

Because we were interested in how barrio-level predictors could explain variance at both the municipal and barrio levels, we calculated multilevel goodness of fit $\left(\mathrm{R}^{2}\right)$ as the proportion of explained variance at the barrio and municipality levels, using methods derived from Gelman and Pardoe (2006).

To evaluate the unique contribution of each predictor, we calculated multilevel $\mathrm{R}^{2}$ for each of the submodels formed by dropping predictors from the best model. By comparing $\mathrm{R}^{2}$ between these submodels and the best model, we inferred the degree to which the missing predictor uniquely contributed to the $\mathrm{R}^{2}$ in the full model.
Residuals of the best model were tested for spatial autocorrelation using Moran's I test. In all four cases there was no evidence of spatial autocorrelation so no adjustments of standard errors were required. All statistical analyses were conducted in R 2.10 ( R Development Team 2010).

\section{RESULTS}

Total forest cover increased dramatically during our first time period (1977-1991) but only slightly from 1991 to 2000 (Fig. 2). Analysis of deforestation patterns between 1977 and 2000 indicates that forest was most likely to be replaced by pasture, followed by urban land cover (Appendix Table A3). During the first period there were clear spatial signatures for both reforestation and deforestation, with reforestation concentrated in the abandoned coffeegrowing regions in western Puerto Rico and deforestation around major cities and along the coast (Fig. 2). The spatial trends in the second period were similar, but the magnitude of change was smaller. 
Fig. 3. Estimated annual deforestation and reforestation rates during the two study periods for the (A) three life zones (with all other covariates set to their mean values) and standardized regression coefficients for (B) slope, (C) soil agricultural capacity, (D) population density, (E) percentage of municipality in protected areas, (F) average income (in 2000 US\$), (G) population growth rates during the analyses period, and $(\mathrm{H})$ total amount of forest (only included in reforestation models). Bars indicate two standard errors above and below estimated means.
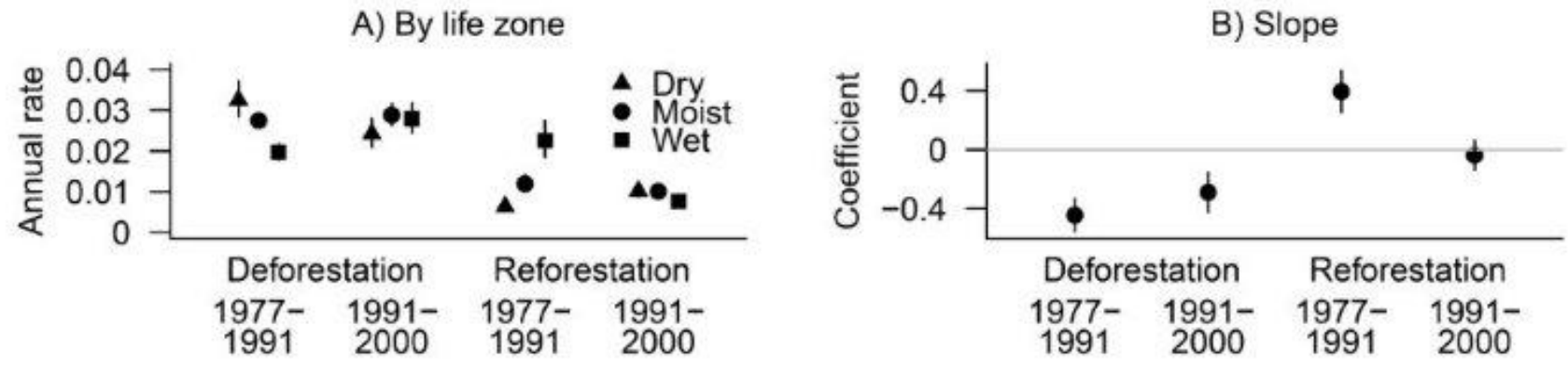

C) Agricultural Capacity
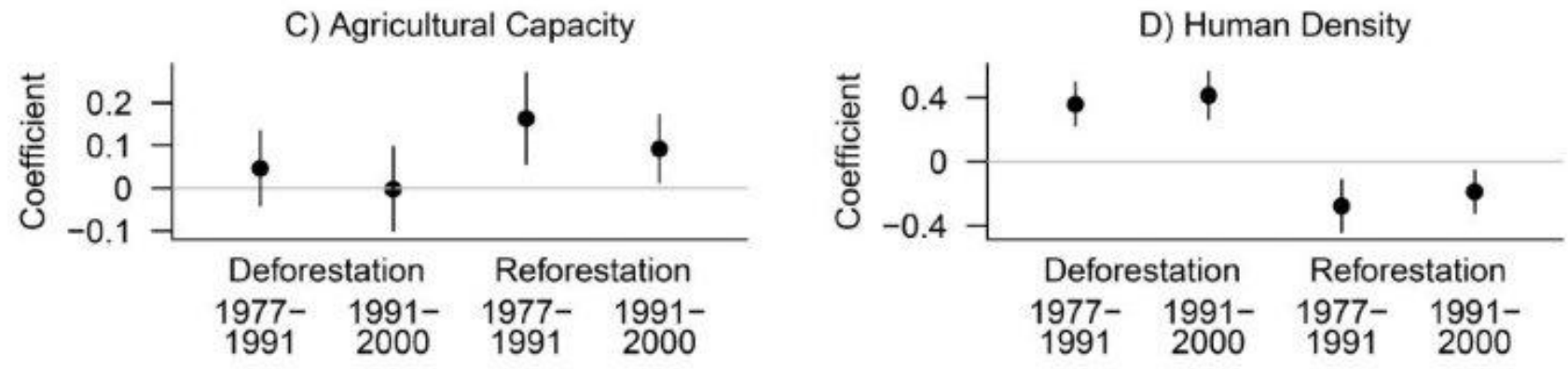

E) Protected Areas
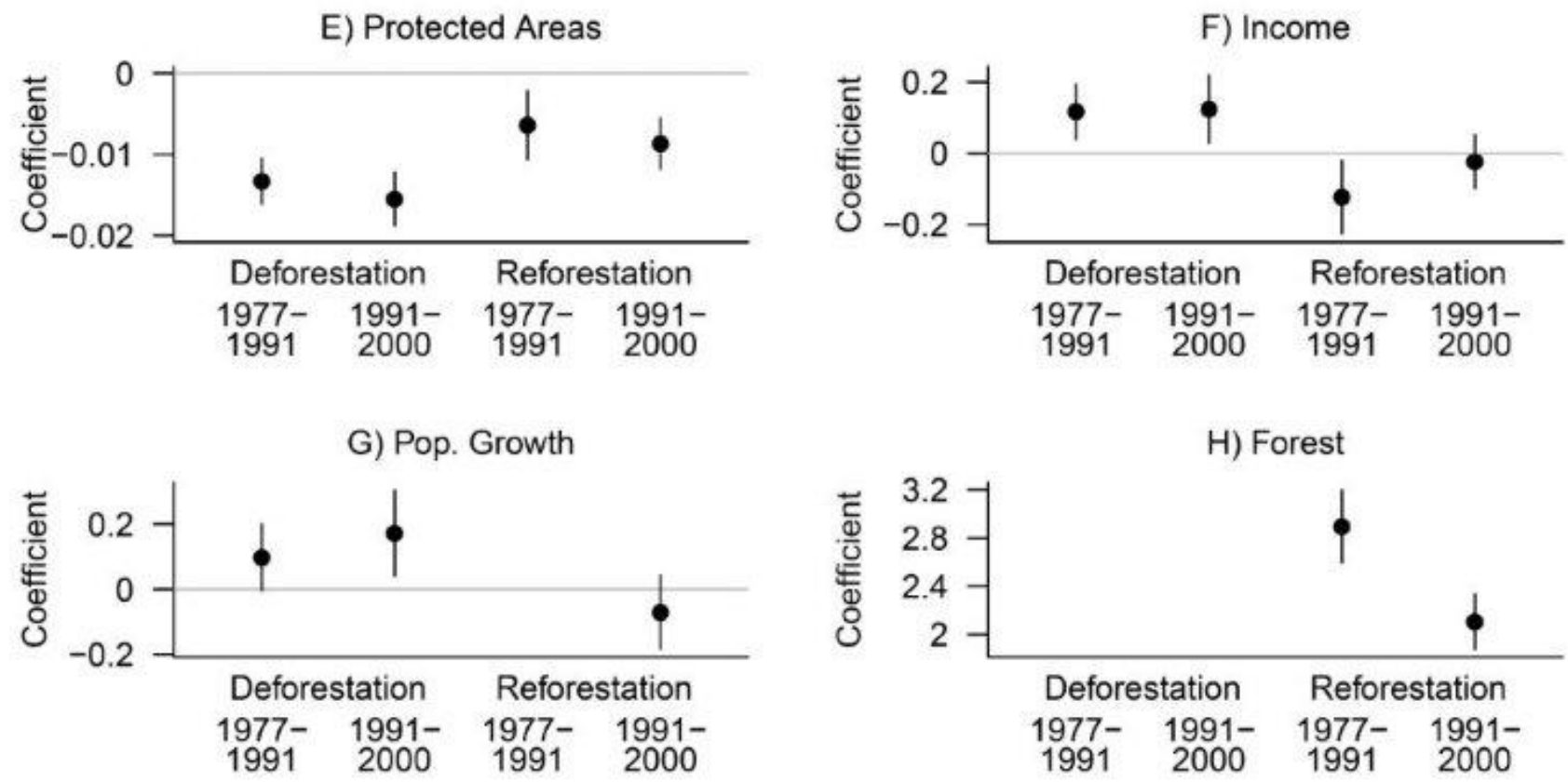
Although there were idiosyncrasies between the different time periods and processes, there were also general patterns in the significance and magnitude of the predictors that generally supported our hypotheses (Table 1, Fig. 3). In general, greater per capita income, population growth, and population density led to greater deforestation and lower reforestation. Areas with steeper slopes and lower soil fertility were more likely to reforest than flatter slopes and more fertile soils whereas the reverse was true for deforestation. As we hypothesized, most variables made mirror predictions (with opposite signs) for reforestation and deforestation (Fig. 3), with two exceptions. Agricultural capacity had positive effects on both reforestation and deforestation over the study period. Areas with protected status had lower rates of both deforestation and reforestation.

Most variables had similar effect sizes among the first and second time periods (Fig. 3), with two important exceptions. Areas with high mean slopes had increased rates of reforestation in the first period only. Similarly, variation between life zones in deforestation and reforestation rates was much greater during the first period (Figs. 3 and 4) with deforestation concentrated in the drier life zones and reforestation concentrated in the wettest areas.

The efficacy of models in explaining variance at each scale varied depending on the time period and transition type (Table 2), and the factors that uniquely explained the most variance often differed between scales of analysis. At the municipality scale, the models' efficacy $\left(\mathrm{R}^{2}\right)$ in explaining patterns of deforestation decreased over time whereas the opposite was true for reforestation (Table 2). At the barrio scale, predictors of deforestation accounted for a greater proportion of the variance in 1977-1991 than in 1991-2000 but we did not find any difference in the efficacy of the reforestation model. Through the use of multilevel $\mathrm{R}^{2}$, we were able to explore the degree to which individual predictors explained variance in reforestation and deforestation across the two time periods at both the municipality and submunicipality scales. Results are outlined in Table 2.

- Deforestation 1977-1991: Removal of life zones from the model led to a large drop in explained variance at the municipio scale (Table 2). At the barrio level, however, removal of life zones led to little change in explained variance. In contrast, removal of percent protected area led to a large drop in explained variance at the barrio but not at the municipal scale.

- Deforestation 1991-2000: During this time period, removal of protected areas led to the largest drop in explained variance at both municipal and barrio scales.

- Reforestation 1977-1991: Removal of either life zones or slope led to large drops in explained variance at the municipio scale, but none of the predictors seemed to uniquely explain much variance at the barrio scale.

- Reforestation 1991-2000: Dropping forest cover as a predictor led to large declines in explained variance at both municipio and barrio scales, despite the fact that effect size of forest cover was lower during the second period.

\section{DISCUSSION}

Broadly, our results show that in 1977-1991, forest dynamics in Puerto Rico were primarily driven by the abandonment of marginal agricultural land in the western-central highlands and by the development of pastureland and urban areas along the flat, coastal regions of the island. This agricultural abandonment resulted in net reforestation across the island, in agreement with previous studies that have examined forest transitions in Puerto Rico since the 1950s (Rudel et al. 2000, Brandeis et al. 2007, Helmer et al. 2008). These land use changes mirror the shifts in the island's agricultural production (Rudel et al. 2000), which transitioned away from cash crops like coffee to the production of more perishable commodities that are difficult to import like dairy. It is important to note that Puerto Rico, given its special relationship with the U.S., was able to make the transition away from agriculture relatively quickly given the availability of inexpensive food imports (Lopez et al. 2001).

Our results illustrate a very different pattern of forest transition during the 1991-2000 period. Unlike in the earlier decades, abandonment of agriculture, as indicated by forest regrowth in former coffee growing regions, i.e., steep terrain, wet life zone, was not a strong driver of reforestation. Instead, 
Fig. 4. Distribution of life zones in Puerto Rico (Daly et al. 2003).

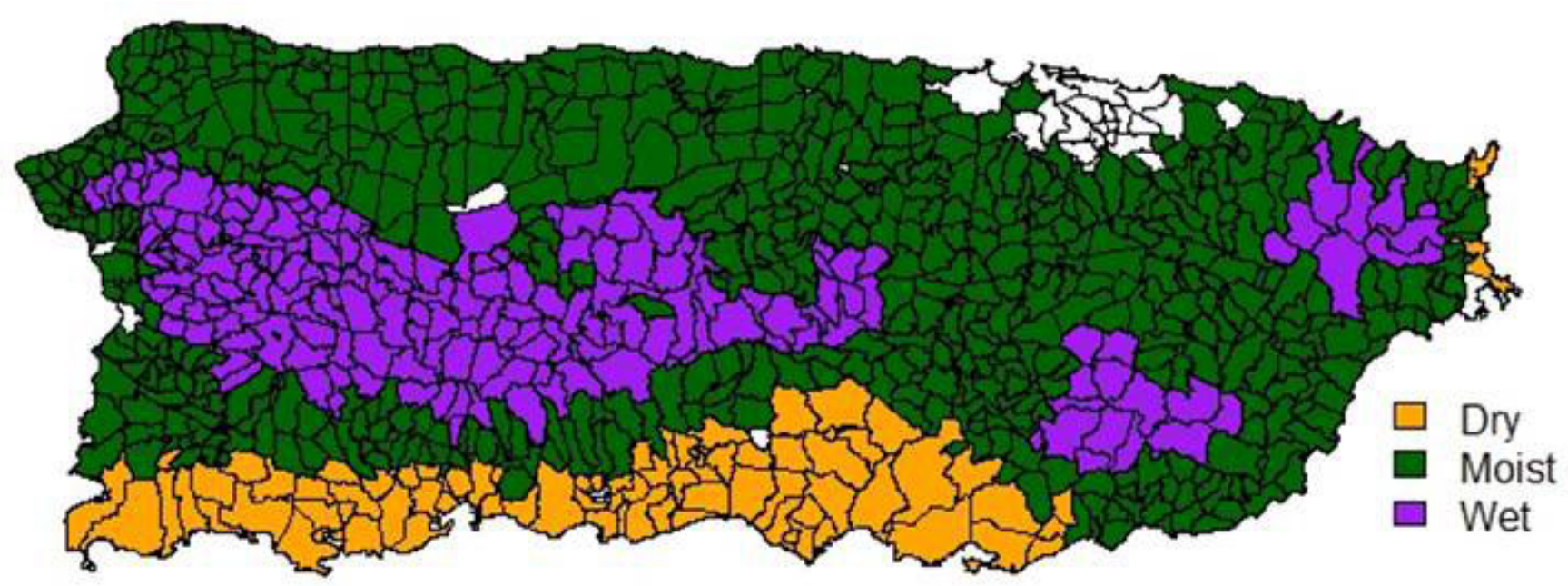

presence of remnant forest cover was the most important explanatory factor, possibly due to greater dispersal of forest tree seeds to open areas close to forest patches relative to those far from forested land (Thomlinson et al. 1996, Aide et al. 2000, Helmer 2004, Crk et al. 2009). Deforestation, on the other hand, was influenced by a variety of biophysical and socioeconomic factors, such as slope, population growth, and income, which drive local development patterns based on relative land values (Barbier et al. 2010). Flatter areas that had higher population densities and where people had more income were more likely to be deforested, possibly because of increased suburbanization pressure (Thomlinson and Rivera 2000, MacDonald and Rudel 2005, Parés-Ramos et al. 2008). Furthermore, deforestation was least likely in areas that prohibited development. This suggests that without effective policies in place for managing secondary forests, such as protected areas, increasing urban expansion may cause a reversal in forest gains (Helmer et al. 2008, Crk et al. 2009).

Our general conclusions support previous findings of the drivers of forest change in Puerto Rico while our specific analyses provide a number of new insights into the forest transition theory. First, we comprehensively quantify the relative importance of biophysical and socioeconomic factors associated with forest change at subnational scales by simultaneously considering factors found to be important in previous individual studies. This is important because previous studies have either focused on national-scale processes (Rudel et al. 2000) or examined only a few social and biophysical drivers of subnational forest change (e.g., Thomlinson et al. 1996, Helmer et al. 2008, ParésRamos et al. 2008). We find that biophysical factors that show variation at municipality scales, e.g., life zones, percent forest cover, were the best predictors of forest change at subnational levels. Life zones were especially good predictors of deforestation and reforestation during the first time period at the larger municipality scale (Table 2). Although forest transitions are often imputed to socioeconomic drivers (Mather et al. 1999, Rudel et al. 2005), our analysis indicates that biophysical factors are at least equally important in mediating local patterns of deforestation and reforestation at subnational scales. This result, however, must be interpreted in the context of broader socioeconomic changes that occurred across the island, namely the shift from agricultural to dairy production and subsequent rural to urban migration (Rudel et al. 2000).

Second, we show how the importance of individual drivers changes with the spatial scale of analysis. Previous studies have typically examined the drivers of forest transitions at one spatial scale and have not quantified how the relative importance of these drivers change across scales (e.g., Thomlinson et al. 1996, Helmer et al. 2008, Parés-Ramos et al. 
Table 2. Explained variance at barrio (submunicipality) and municipio levels for best models of deforestation and reforestation during two time periods (1977-1991 and 1991-2000) and explained variance in models where individual explanatory variables are removed from best model. The decrease in $\mathrm{R}^{2}$ relative to the best model indicates the importance of that variable in predicting observed transitions. The best model does not necessarily have the best $\mathrm{R}^{2}$ at a particular scale because model selection is based on the overall agreement between data and the model; in other words, the ability to simultaneously explain variance at all levels of a multilevel model.

\begin{tabular}{|c|c|c|c|c|c|c|c|c|}
\hline & \multicolumn{4}{|c|}{ Deforestation } & \multicolumn{4}{|c|}{ Reforestation } \\
\hline & \multicolumn{2}{|c|}{$1977-1991$} & \multicolumn{2}{|c|}{$1991-2000$} & \multicolumn{2}{|c|}{$1977-1991$} & \multicolumn{2}{|c|}{$1991-2000$} \\
\hline & Barrio & Municipio & Barrio & Municipio & Barrio & Municipio & Barrio & Municipio \\
\hline Best Model & 0.53 & 0.64 & 0.45 & 0.24 & 0.64 & 0.49 & 0.63 & 0.64 \\
\hline \multicolumn{9}{|l|}{ Variable removed } \\
\hline Life Zones & 0.52 & 0.49 & 0.45 & 0.23 & 0.60 & 0.22 & 0.62 & 0.63 \\
\hline Slope & 0.50 & 0.62 & 0.44 & 0.21 & 0.63 & 0.38 & 0.63 & 0.63 \\
\hline Agricultural Capacity & 0.53 & 0.65 & 0.46 & 0.23 & 0.63 & 0.50 & 0.62 & 0.64 \\
\hline Forest Cover & & & & & 0.60 & 0.55 & 0.48 & 0.32 \\
\hline Human Density & 0.52 & 0.64 & 0.43 & 0.20 & 0.64 & 0.50 & 0.63 & 0.65 \\
\hline Percentage Protected Area & 0.46 & 0.63 & 0.39 & 0.19 & 0.64 & 0.47 & 0.62 & 0.60 \\
\hline Mean Income & 0.52 & 0.67 & 0.45 & 0.21 & 0.63 & 0.52 & 0.63 & 0.64 \\
\hline Population Growth & 0.53 & 0.65 & 0.45 & 0.21 & NA & NA & 0.63 & 0.64 \\
\hline
\end{tabular}

2008). Life zones were weaker predictors of reforestation and deforestation at the smaller barrio scale than at the municipality scale. This is not surprising given that reforestation and deforestation were spatially clustered at the regional level, resulting in limited variation in reforestation and deforestation within life zones at the finer barrio scale. Deforestation rates were best explained by the absence of protected areas during both time periods, especially at the barrio scale. This is not surprising given that expansion of pastureland and urban areas were the main sources of deforestation (Appendix Table 3), and protected areas legally prohibited this development. In the second time period and in contrast to the first time interval, drivers of deforestation and reforestation were similar across spatial scales. Finally, the predictive efficacy of the model changed across spatial scales highlighting the scale at which variation in deforestation and reforestation occurs. For instance, in the 1977-1991 period, our model captured patterns of deforestation better at the municipality scale than at the barrio scale, highlighting the importance of large-scale biophysical factors in mediating deforestation dynamics. The opposite was true for the 1991-2000 period for which our model did a better job capturing patterns of deforestation at the barrio than at the municipal level. In all likelihood, patterns of deforestation in this time period exhibited a patchy, fine-grained spatial pattern, reflecting suburbanization pressures.

Third, our analyses also suggest that examining forest transitions during multiple time periods is important given that the drivers of reforestation and deforestation in Puerto Rico changed markedly between our two study periods. For example, during the first time period characterized by high levels of 
agricultural abandonment and rural to urban migration, life zones were the best predictor of reforestation. During the second time period, however, when these broad socioeconomic patterns were less marked, percent forest cover was the best predictor of reforestation. Similarly, deforestation rates were best explained by life zones during the first time period because of development of pastureland and urban areas on dry, flat lands. Absence of protected areas, however, was the best predictor of deforestation in the second time period, pointing to increasing deforestation pressure from land development. These results highlight that, to understand the dynamic nature of forest transitions and their causes, it is important to consider multitemporal scale analyses. Our results add to an increasing body of literature showing the dynamic nature of LUCC drivers (e.g., DeFries et al. 2010).

Finally, our analyses show that examining net forest transitions may obscure the factors driving forest change through reforestation and deforestation. Although these two processes largely mirror each other, they are also associated with different factors depending on the spatial and temporal scales of analysis (Asner et al. 2009). These results suggest that reforestation and deforestation often have different drivers, and therefore should be examined and managed separately.

These results have important implications for land use policy. First, broader socioeconomic changes in a given region or even globally may drive demand for land, but biophysical factors ultimately mediate where development occurs. In the case of Puerto Rico, a socioeconomic transition away from agriculture led to the abandonment of agricultural lands, however, biophysical factors influenced which areas were actually abandoned and subsequently reforested. These patterns were the result of variations in topography. In agreement with this result, a recent review by Asner et al. (2009) found that a majority of reported forest transitions occurred in areas with steep topography. Second, our results suggest that even though socioeconomic development may result in net reforestation levels at the national level, actual reforestation and deforestation patterns vary subnationally. This is important to note given that net reforestation may mask the loss of important primary and secondary forests at the subnational scale. Finally, our results highlight that although economic development may initially result in reforestation because of rural to urban migration and the abandonment of agricultural lands as predicted by FT Theory, increased economic development may lead to deforestation through increased suburbanization pressures. In fact, previous studies have suggested that as people's purchasing power increases, they prefer to migrate to low-density suburban areas near existing forest cover, resulting in significant deforestation (Thomlinson and Rivera 2000, ParésRamos et al. 2008).

One important caveat to our study is the degree to which our findings can be generalized to other tropical regions across the globe. Puerto Rico is unique compared with much of the tropics given its special relationship with the United States and its high population density and subsequent high demand for urban cover. Thus, factors that drove forest dynamics in Puerto Rico may not be important in other tropical regions that have no ties to large industrialized countries and have low rates for urban development. Considering Puerto Rico's special relationship with the United States, we argue that the industrialization process in Puerto Rico was only the initial economic trigger and that the present drivers of forest transition, e.g., land values, reflect general processes at work in other developing tropical regions (Grau et al. 2003). Furthermore, although broad national-scale forest transitions vary across the tropics, we argue that an increasing demand for agricultural products, urban cover, and development that is being driven by globalization and increased wealth across the tropics (Hecht et al. 2006, Perz 2007, DeFries et al. 2010) will result in similar local-scale drivers of reforestation and deforestation over the upcoming decades. The importance of land value for explaining local-level forest change is supported by similar findings from other tropical regions: reforestation is concentrated in rural, higher-altitude municipalities while deforestation is concentrated on the coast in southern Brazil (Baptista 2008), forest cover is concentrated in low population density, low income districts in Panama (Wright and Samaniego 2008), and land abandonment and subsequent reforestation is more frequent in farms with marginal soil quality and high forest cover in southern Chile (Díaz et al. 2011). We expect our results to most directly apply to other regions that have already undergone a significant amount of forest recovery and are rapidly developing, such as Hong Kong, Taiwan, and other Caribbean islands. Our results, however, may not apply to sparsely populated areas with flat topography and high potential for commercial agriculture (Grau and Aide 2008, Asner et al. 2009). 
Our study suggests that to understand the complexity of forest transitions in the tropics, it is important to monitor such transitions at different temporal and spatial scales, and place them in dynamic social and institutional settings. Land transformations need to be considered as an intricate cycle where human decisions affect the landscape, altered landscapes affect ecological processes, these processes influence the way humans monitor and respond to land transformations, and these responses set in motion a new set of social drivers of land use change. Temporally, human transformations of landscapes are driven by historical and current social, economic, and ecological drivers (de Jong 2010, Lawrence et al. 2010). Spatially, these transformations respond not only to local needs and concerns but also to regional and global drivers. Understanding forest transition dynamics will improve the ability of decision makers to promote forest conservation and regrowth at multiple spatial scales and increase our understanding of how deforestation and reforestation drivers can change over time.

Responses to this article can be read online at: http://www.ecologyandsociety.org/voll6/iss3/art15/ responses/

\section{Acknowledgments:}

We thank the editor and two anonymous reviewers for useful comments on a previous version on the manuscript. We also thank Dr. Vivian CarroFigueroa from USDA Extension Service for helpful discussions about agricultural policy and history in Puerto Rico. This work was supported by grants from NSF to the Luquillo Long-Term Ecological Research Program. The U.S. Forest Service and the University of Puerto Rico provided additional support. We also received partial support from the Earth Institute, Columbia University.

\section{LITERATURE CITED}

Aide, T. M., J. K. Zimmerman, J. B. Pascarella, L. Rivera, and H. Marcano-Vega. 2000. Forest regeneration in a chronosequence of tropical abandoned pastures: implications for restoration ecology. Restoration Ecology 8:328-338. http://dx. doi.org/10.1046/j.1526-100x.2000.80048.x
Asner, G. P., T. K. Rudel, T. M. Aide, R. DeFries, and R. Emerson. 2009. A contemporary assessment of change in humid tropical forests. Conservation Biology 23:1386-1395. http://dx.doi.org/10.1111/j. 1523-1739.2009.01333.x

Barbier, E. B., J. C. Burgess, and A. Grainger. 2010. The forest transition: towards a more comprehensive theoretical framework. Land-use Policy 27:98-107. http://dx.doi.org/10.1016/j.landusepol.2009.02.001

Brandeis, T. J., E. H. Helmer, and S. N. Oswalt. 2007. The status of Puerto Rico's forests, 2003. Resource Bulletin SRS-119, U.S. Forest Service Southern Research Station, Asheville, North Carolina, USA.

Baptista, S. R. 2008. Metropolitanization and forest recovery in southern Brazil: a multiscale analysis of the Florianopolis city-region, Santa Catarina State, 1970 to 2005. Ecology and Society 13(2): 5. [online] URL: http://www.ecologyandsociety.org/vol13/ iss2/art5/

Crk, T., M. Uriarte, F. Corsi, and D. B. F. Flynn. 2009. Forest recovery in a tropical landscape: what is the relative importance of biophysical, socioeconomic, and landscape variables? Landscape Ecology 24:629-642. http://dx.doi.org/10.1007/s10 980-009-9338-8

Daly, C., E. H. Helmer, and M. Quiñones. 2003. Mapping the climate of Puerto Rico, Vieques and Culebra. International Journal of Climatology 23:1359-1381. http://dx.doi.org/10.1002/joc.937

DeFries, R., T. K. Rudel, M. Uriarte, and M. Hansen. 2010. Deforestation driven by urban population growth and agricultural trade in the twenty-first century. Nature Geoscience 3:178-181. http://dx.do i.org/10.1038/ngeo756

de Jong, W. 2010. Forest rehabilitation and its implication for forest transition theory. Biotropica 42:3-9. http://dx.doi.org/10.1111/j.1744-7429.2009 $.00568 . \mathrm{x}$

Díaz, G. I., L. Nahuelhual, C. Echeverria, and S. Marin. 2011. Drivers of land abandonment in southern Chile and implications for landscape planning. Landscape and Urban Planning 99:207-217. http://dx.doi.org/10.1016/j.landurbplan .2010.11.005 
Dietz, J. L. 1986. Economic history of Puerto Rico, Institutional change and capitalist development. Princeton University Press, Princeton, New Jersey, USA.

Gelman, A., and D. B. Rubin. 1992. Inference from iterative simulation using multiple sequences. Statistical Science 7:457-472. http://dx.doi.org/10.1 214/ss/1177011136

Gelman, A., and L. Pardoe. 2006. Bayesian measures of explained variance and pooling in multilevel (hierarchical) models. Technometrics 48:241-251. http://dx.doi.org/10.1198/0040170050 $\underline{00000517}$

Gould, W., C. Alarcón, B. Fevold, M. E. Jiménez, S. Martinuzzi, G. Potts, M. Solórzano, and E. Ventosa. 2007. Puerto Rico gap analysis project final report. U.S. Geological Survey, Moscow ID and the U.S. Forest Service. International Institute of Tropical Forestry, Río Piedras, Puerto Rico.

Grau, H. R., and M. Aide. 2008. Globalization and land-use transitions in Latin America. Ecology and Society 13(2): 16. [online] URL: http://www.ecolo gyandsociety.org/vol13/iss2/art16/

Grau, H. R., T. M. Aide, J. K. Zimmerman, J. R. Thomlinson, E. H. Helmer, and X. Zou. 2003. The ecological consequences of socioeconomic and land-use changes in post-agriculture Puerto Rico. Bioscience 53:1159-1168. http://dx.doi.org/10.1641 /0006-3568(2003)053[1159:TECOSA]2.0.CO;2

Hecht, S., S. Kandel, I. Gomes, N. Cuellar, and H. Rosa. 2006. Globalization, forest resurgence, and environmental politics in El Salvador. World Development 34:308-323. http://dx.doi.org/10.1016/ j.worlddev.2005.09.005

Helmer, E. H. 2004. Forest conservation and land development in Puerto Rico. Landscape Ecology 19:29-40. http://dx.doi.org/10.1023/B:LAND.0000 $\underline{018364.68514 . \mathrm{fb}}$

Helmer, E. H., T. J. Brandeis, A. E. Lugo, and T. Kennaway. 2008. Factors influencing spatial pattern in tropical forest clearance and stand age: implications for carbon storage and species diversity. Journal of Geophysical ResearchBiogeosciences 113, G02S04. http://dx.doi.org/10.1 $\underline{\text { 029/2007JG000568 }}$
Hunter, J. M., and S. I. Arbona. 1995. Paradise lost: an introduction to the geography of water pollution in Puerto Rico. Social Science \& Medicine 40:1331-1355. http://dx.doi.org/10.1016/0277-9536 (94)00255-R

Irwin, E. G., and N. E. Bockstael. 2007. The evolution of urban sprawl: evidence of spatial heterogeneity and increasing land fragmentation. Proceedings of the National Academy of Sciences of the United States of America 104:20672-20677. http://dx.doi.org/10.1073/pnas.0705527105

Izquierdo, A. E., C. D. De Angelo, and T. M. Aide. 2008. Thirty years of human demography and landuse change in the Atlantic forest of Misiones, Argentina: an evaluation of the forest transition model. Ecology and Society 13(2): 3. [online] URL: http://www.ecologyandsociety.org/vol13/iss2/art3/

Kennaway, T., and E. H. Helmer. 2007. The forest types and ages cleared for land development in Puerto Rico. GIScience and Remote Sensing 44:356-382. http://dx.doi.org/10.2747/1548-1603.4 $\underline{4.4 .356}$

Lambin, E. F., and H. J. Geist, editors. 2006. Landuse and land-cover change: local processes and global impacts. The IGBP Series. Springer, Berlin, Germany.

Lawrence, D., C. Radel, K. Tully, B. Schmook, and L. Schneider. 2010. Untangling a decline in tropical forest resilience: constraints on the sustainability of shifting cultivation across the globe. Biotropica 42:21-30. http://dx.doi.org/10.1111/j.1744-7429.20 09.00599.x

Lopez, T., T. M. Aide, and J. R. Thomlinson. 2001. Urban expansion and the loss of prime agricultural lands in Puerto Rico. Ambio 30(1):49-54.

MacDonald, K., and T. K. Rudel. 2005. Sprawl and forest cover: what is the relationship? Applied Geography 25:67-79. http://dx.doi.org/10.1016/j.ap geog.2004.07.001

Margo, R. 1992. Explaining the postwar suburbanization of population in the United States: the role of income. Journal of Urban Economics 31 (3):301-310. http://dx.doi.org/10.1016/0094-1190(92) $\underline{\text { 90058-S }}$ 
Martinuzzi, S., W. A. Gould, and O. M. R. González. 2007. Land development, land-use, and urban sprawl in Puerto Rico integrating remote sensing and population census data. Landscape and Urban Planning 79:288-297. http://dx.doi.org/10.1016/j.la ndurbplan.2006.02.014

Mather, A. S. 1992. The forest transition. Area 24:367-379.

Mather, A. S., and C. L. Needle. 1998. The forest transition: a theoretical basis. Area 30:117-124. htt p://dx.doi.org/10.1111/j.1475-4762.1998.tb00055.x

Mather, A. S., C. L. Needle, and J. Fairbairn. 1999. Environmental kuznets curves and forest trends. Geography 84:55-65.

Meyfroidt, P., and E. F. Lambin. 2009. Forest transition in Vietnam and displacement of deforestation abroad. Proceedings of the National Academy of Sciences of the United States of America 106:16139-16144. http://dx.doi.org/10.1073/pnas.0 $\underline{904942106}$

Parés-Ramos, I. K., W. A. Gould, and T. M. Aide. 2008. Agricultural abandonment, suburban growth, and forest expansion in Puerto Rico between 1991 and 2000. Ecology and Society 13(2): 1. [online] URL: http://www.ecologyandsociety.org/vol13/iss2/ $\underline{\operatorname{art} 1 /}$

Perz, S. G. 2007. Grand theory and contextspecificity in the study of forest dynamics: forest transition theory and other directions. Professional Geographer 59:105-114. http://dx.doi.org/10.1111/ j.1467-9272.2007.00594.X

Perz, S. G., and D. L. Skole. 2003 Secondary forest expansion in the Brazilian Amazon and the refinement of forest transition theory. Society and Natural Resources 16:277-294. http://dx.doi.org/10 $\underline{.1080 / 08941920390178856}$

Pfaff A., and R. Walker. 2010. Regional interdependence and forest "transitions": substitute deforestation limits the relevance of local reversals. Land Use Policy 27:119-129. http://dx.doi.org/10.1 $\underline{\text { 016/j.landusepol.2009.07.010 }}$

Ramos, O. M., and A. E. Lugo. 1994. Mapa de la vegetación de Puerto Rico. Acta Cientifica 8:63-66.
Rudel, T. K., M. Perez-Lugo, and H. Zichal. 2000. When fields revert to forests: development and spontaneous reforestation in post-war Puerto Rico. Professional Geographer 52:386-397. http://dx.doi. org/10.1111/0033-0124.00233

Rudel, T. K., O. T. Coomes, E. Moran, F. Achard, A. Angelsen, J. Xu, and E. Lambin. 2005. Forest transitions: towards a global understanding of land use change. Global Environmental Change 15:23-31. http://dx.doi.org/10.1016/j.gloenvcha.20 $\underline{04.11 .001}$

Rudel, T. K., L. Schneider, M. Uriarte, B. L. Turner II, R. Defries, D. Lawrence, J. Geoghegan, S. Hecht, A. Ickowitz, E. F. Lambin, T. Birkenholtz, S. Baptista, and R. Grau. 2009. Agricultural intensification and changes in cultivated areas, 1970-2005. Proceedings of the National Academy of Sciences of the United States of America 106:20675-20680. http://dx.doi.org/10.1073/pnas.0 $\underline{812540106}$

R Development Team. 2010. R: A language and environment for statistical computing. R Foundation for Statistical Computing, Vienna, Austria.

Southworth, J. S., and C. Tucker. 2001. The influence of accessibility, local institutions, and socioeconomic factors on forest cover change in the mountains of western Honduras. Mountain Research and Development 21:276-283. http://dx.d oi.org/10.1659/0276-4741(2001)021[0276:TIOALI] 2.0.CO;2

Spiegelhalter, D. J., N. G. Best, B. R. Carlin, and A. van der Linde. 2002. Bayesian measures of model complexity and fit. Statistical Methodology 64 (4):583-639.

Thomlinson, J. R., M. I. Serrano, T. del M. Lopez, T. M. Aide, and J. K. Zimmerman. 1996. Land-use dynamics in a post-agricultural Puerto Rican landscape (1936-1988). Biotropica 28(4):525-536. http://dx.doi.org/10.2307/2389094

Thomlinson, J. R., and L. Y. Rivera. 2000. Suburban growth in Luquillo Puerto Rico: some consequences of development on natural and semi-natural systems. Landscape and Urban Planning 49:15-23. http://dx.doi.org/10.1016/S0169-2046(00)00056-6 
Turner, M., D. Wear, and R. Flamm. 2009. Land ownership and land-cover change in the Southern Appalachian Highlands and the Olympic Peninsula. Ecological Applications 6:1150-1172.

U.S. Bureau of the Census. 1980, 1990, and 2000. Census of population: social and economic characteristics. Department of Commerce, Economics, and Statistics Administration, Washington, D.C., USA.

U.S. Department of Agriculture Natural Resources Conservation Service (USDA NRCS). 2007. National soil survey handbook, title 430-VI Part 622. USDA NRCS, Washington, D.C., USA. [online] URL: http://soils.usda.gov/technical/handbook/

U.S. Geological Survey (USGS). 2009. Shuttle radar topography mission (SRTM)_- "Finished". U.S. Geological Survey, Reston, Virginia, USA. [online] URL: http://eros.usgs.gov/\#/Find Data/Pro ducts and Data Available/SRTM

Weisskoff, R., and E. Wolff. 1977. Linkages and leakages: industrial tracking in an enclave economy. Economic Development and Cultural Change 25:607-28.

Wright, S. J., and M. J. Samaniego. 2008. Historical, demographic, and economic correlates of land-use change in the Republic of Panama. Ecology and Society 13(2): 17. [online] URL: http://www.ecolog yandsociety.org/vol13/iss2/art17/ 


\section{Appendix 1: Mapping Methodology}

This study is based on analyses of land-cover change derived from three land-cover maps (1977-78, 1991, 2000). Land-cover maps for 1991 and 2000 were derived from Landsat TM and ETM + mosaics of images taken at $30 \mathrm{~m}$ resolution (Kennaway and Helmer 2007). The 1977-78 maps were derived from vector-based, photo-interpreted maps of forest cover. Potential problems with this approach to the study of land-cover change are related to challenges in post-classification change detection, reconciling different data types, and differences between aerial photo interpretation and machine imagery classification. In change detection using classified images, misclassification errors can accumulate through time. Nevertheless, this approach was used successfully by Kennaway and Helmer (2007) and Helmer et al. (2008).

Reconciliation of the vector-based (1977-78) and pixel-based (1991-2000) mapping methods was made easier by the relatively good geo-registration between the two methods. In order to compare all three maps, we used ArcGIS 9.2 to correct minor boundary errors between the 1977-78 images, rasterize the 1977 map (a 30 m cell size was assigned to the 1977-78 map by majority rule), and calculate total forest area and transitions across time periods (1977-1991 and 1991-2000). Residual misregistration errors between the rasterized 1977-78 vector boundaries and the 1991 pixel-based map can be mistaken for land-cover change. Differences between aerial photo interpretation and machine classification of satellite imagery can also affect the accuracy of detecting various types of changes. Although manual photo interpretation and machine classification can both result in detailed classification schemes (see Tables A1 and A2), we conservatively restricted them to eight distinct classes. Classification of moderate-resolution (e.g., $30 \mathrm{~m}$ ) satellite imagery often results in scattered misclassified pixels, but it may also correctly identify small patches that a manual interpreter would aggregate into different classes (Kennaway and Helmer 2007).

Although gross errors in classification of individual land-covers are possible between the 1977-78 and 1991 maps, they are unlikely. Despite widespread shifts in land-cover and agricultural production (Appendix Table 3), there is great concordance between the 1977-78 and 1991 maps (52.0\% identical). The 1977-78 and 1991 maps differ most in the forest cover of the western highlands, which remain forested today (Brandeis et al. 2007). Large declines in Puerto Rican coffee production immediately preceded agricultural abandonment of the western uplands (Fagan, unpublished data), lending indirect support to the accuracy of the 1977-78 and 1991 maps. Finally, only 5.3\% of the 1977-78 and 1991 maps appear to be obviously misclassified change (i.e., loss of urban cover, or conversion from land to water).

During our study period, urban cover increased from 12.1 to $15.5 \%$ of island area, and forest cover increased from 34.8 to $45.1 \%$ of island area. Although our figure of $45.1 \%$ forest cover contrasts with the $57 \%$ forest cover reported by Brandeis et al. (2007), this is likely because of differences in methodology and imagery resolution. Brandeis et al. (2007) used high-resolution photos to map forest cover over the island, and defined forest as land with greater than $10 \%$ forest cover. It is unsurprising that our moderateresolution land-cover maps have lower forest cover, because coarser-resolution images typically underestimate true forest cover (Fagan and DeFries 2009). Non-forest areas with small patches of forest interspersed (e.g., pastures, suburbs, etc.) would have their forest patches mapped in high-resolution imagery, while moderate-resolution imagery would be classified to the dominant land-cover type. Similarly, the expansive forest definition employed by Brandeis et al. (2007) would cause small changes 
in tree cover from 1990 to 2004 to count as much greater changes in forest area than those observed by Landsat. In effect, the Landsat estimate of forest area is more conservative, but not inaccurate as a measure of large-scale change. We refer the interested reader to Brandeis et al. (2007), who discuss this issue extensively. Our estimates of forest cover agree with those of Pares-Ramos et al (2008) who use a different methodology and higher-resolution imagery to arrive at $52.4 \%$ forest cover. Our estimate of urban cover in 2000 is higher than that of Pares-Ramos et al. (2008) (11.3\% of island area), but their lower estimate likely arises from their higher-resolution mapping and the relatively small building footprint of suburban development in Puerto Rico.

Because of the merging of land-cover classes and the source of the 1977-78 maps, it is difficult to evaluate the overall accuracy of the three land-cover maps. The accuracy of the 1991 and 2000 imagery was quantified by Kennaway and Helmer (2007); these maps correctly classified $72 \%$ and $82 \%$ of points, respectively, with an error matrix having Kappa coefficients of $0.69 \pm 0.02$ and $0.81 \pm 0.02$. Due to aggregation from 29 to eight land-cover classes, the accuracy of the 1991 and 2000 maps is higher than reported in Kennaway and Helmer (2007). However, we lack an estimate of accuracy for the 1977-78 map. Although we cannot quantify the classification accuracy of the 1977-78 map, the aerial photos were interpreted by a team of professional photo interpreters using sound methodology (DNRA 1998) (Table A1). Therefore, we assume low classification error for the 1977-78 land-use map. The analyses in this study assume that none of the potential error sources discussed here are large enough to influence our conclusions. In addition, forest change from 1977-1991 was dramatic, providing a strong signal-to-noise ratio, while most of the urban forest change occurred from 1991-2000, a period for which we have an estimate of error (Kennaway and Helmer 2007). 
Table A1: Class conversions from the original 1977 map to the classifications used in our analyses. The twelve land-cover classes in the 1977 land-cover map discussed by Ramos and Lugo (1994) were reduced to eight classes in our analysis, following the same methodology as Crk et al. (2009).

\begin{tabular}{|lccl|}
\hline Original 1977 class & Old Class & New Class & New Class Name \\
\hline $\begin{array}{l}\text { Development, non-productive } \\
\text { land }\end{array}$ & 12 & 1 & Urban/developed \\
\hline Agriculture & 2 & 2 & $\begin{array}{l}\text { Herbaceous/coffee/mixed woody } \\
\text { agriculture }\end{array}$ \\
\hline Pasture & 3 & 3 & Pasture/grass \\
\hline Highly dense canopy forest & 4 & 4 & Forest/woodland/shrubland \\
\hline Dense canopy forest & 5 & 4 & Forest/woodland/shrubland \\
\hline Low canopy density forest & 6 & 4 & Forest/woodland/shrubland \\
\hline Shrub & 7 & 4 & Forest/woodland/shrubland \\
\hline Mangrove & 8 & 5 & Forested wetland \\
\hline Wetlands and salt-flats & 9 & 6 & Non-forest wetland \\
\hline Rocky areas & 10 & 7 & Non-vegetated \\
\hline No class & 13 & -- & No class (omitted) \\
\hline Water bodies & 11 & 8 & Water \\
\hline
\end{tabular}


Table A2: Class conversions from the original 1991 and 2000 maps. The twenty-nine land-cover classes in the 1991 and 2000 land-cover maps created by Kennaway and Helmer (2007) were reduced to eight classes in our analysis, following the same methodology as Crk et al. (2009).

\begin{tabular}{|c|c|c|c|}
\hline Original 1991/2000 Class & Old Class & $\begin{array}{l}\text { New } \\
\text { Class }\end{array}$ & New Class Name \\
\hline High-Medium Density Urban & 1 & 1 & Urban/developed \\
\hline Low-Medium Density Urban & 2 & 1 & Urban/developed \\
\hline Herbaceous Agriculture - Cultivated Lands & 3 & 2 & $\begin{array}{l}\text { Herbaceous/coffee/mixed } \\
\text { woody agriculture }\end{array}$ \\
\hline Active Sun Coffee and Mixed Woody Agriculture & 4 & 2 & $\begin{array}{l}\text { Herbaceous/coffee/mixed } \\
\text { woody agriculture }\end{array}$ \\
\hline $\begin{array}{l}\text { Pasture, Hay or Inactive Agriculture (e.g. } \\
\text { abandoned sugar cane) }\end{array}$ & 5 & 3 & Pasture \\
\hline $\begin{array}{l}\text { Pasture, Hay or other Grassy Areas (e.g. soccer } \\
\text { fields) }\end{array}$ & 6 & 3 & Pasture \\
\hline Drought Deciduous Open Woodland & 7 & 4 & Forest/woodland/shrubland \\
\hline Drought Deciduous Dense Woodland & 8 & 4 & Forest/woodland/shrubland \\
\hline $\begin{array}{l}\text { Deciduous, Evergreen Coastal and Mixed Forest } \\
\text { or Shrubland with Succulents }\end{array}$ & 9 & 4 & Forest/woodland/shrubland \\
\hline $\begin{array}{l}\text { Semi-Deciduous and Drought Deciduous Forest } \\
\text { on Alluvium and Non-Carbonate Substrates }\end{array}$ & 10 & 4 & Forest/woodland/shrubland \\
\hline $\begin{array}{l}\text { Semi-Deciduous and Drought Deciduous Forest } \\
\text { on Karst (includes semi-evergreen forest) }\end{array}$ & 11 & 4 & Forest/woodland/shrubland \\
\hline $\begin{array}{l}\text { Drought Deciduous, Semi-deciduous and Seasonal } \\
\text { Evergreen Forest on Serpentine }\end{array}$ & 12 & 4 & Forest/woodland/shrubland \\
\hline $\begin{array}{l}\text { Seasonal Evergreen and Semi-Deciduous Forest } \\
\text { on Karst }\end{array}$ & 13 & 4 & Forest/woodland/shrubland \\
\hline Seasonal Evergreen and Evergreen Forest & 14 & 4 & Forest/woodland/shrubland \\
\hline Seasonal Evergreen Forest with Coconut Palm & 15 & 4 & Forest/woodland/shrubland \\
\hline $\begin{array}{l}\text { Evergreen and Seasonal Evergreen Forest on } \\
\text { Karst }\end{array}$ & 16 & 4 & Forest/woodland/shrubland \\
\hline Evergreen Forest on Serpentine & 17 & 4 & Forest/woodland/shrubland \\
\hline $\begin{array}{l}\text { Elfin, Sierra Palm, Transitional and Tall Cloud } \\
\text { Forest }\end{array}$ & 18 & 4 & Forest/woodland/shrubland \\
\hline $\begin{array}{l}\text { Emergent Wetlands Including Seasonally Flooded } \\
\text { Pasture }\end{array}$ & 19 & 5 & Non-forest wetland \\
\hline Mangrove & 21 & 6 & Forested wetland \\
\hline Seaonally Flooded Savannahs and Woodlands & 22 & 6 & Forested wetland \\
\hline Pterocarpus Swamp & 23 & 6 & Forested wetland \\
\hline Salt or Mud Flats & 20 & 7 & Non-vegetated \\
\hline Coastal Sand and Rock & 26 & 7 & Non-vegetated \\
\hline Bare Soil (including bulldozed land) & 27 & 7 & Non-vegetated \\
\hline Background/water & 0 & 8 & Water \\
\hline Water - Permanent & 28 & 8 & Water \\
\hline $\begin{array}{l}\text { Tidally Flooded Evergreen Dwarf-Shrubland and } \\
\text { Forb Vegetation }\end{array}$ & 24 & $\mathrm{n} / \mathrm{a}$ & $\mathrm{n} / \mathrm{a}$ \\
\hline Quarries & 25 & $\mathrm{n} / \mathrm{a}$ & $\mathrm{n} / \mathrm{a}$ \\
\hline
\end{tabular}


Table A3: Key land-cover transitions in Puerto Rico, 1977-2000. Land-cover change calculated from the GIS land-cover maps described above. Deforestation measures transitions from forest to non-forest landcovers, and is broken down by non-forest category. Similarly, reforestation marks transitions from nonforest to forest land-covers, broken down by non-forest category. The "other" category includes all other non-forest categories (listed in Table A2). Net forest change subtracts deforestation from reforestation, and urbanization measures transitions from all land-covers to urban cover. Total hectares for the island of Puerto Rico were similar between land-cover transition maps, with minor changes $(0.05 \%$ of total area) due to classification error with water (excluded here). See Kennaway and Helmer (2007) for detailed land transition matrix.

\begin{tabular}{|c|c|c|c|c|}
\hline \multicolumn{3}{|c|}{ 1977-1991 } & \multicolumn{2}{|c|}{ 1991-2000 } \\
\hline & Hectares & Normal \%* & Hectares & Normal \%* \\
\hline \multicolumn{5}{|l|}{ Deforestation } \\
\hline to pasture & 64,272 & 5.31 & 49,077 & 6.31 \\
\hline to agriculture & 4,144 & 0.34 & 9,333 & 1.20 \\
\hline to urban & 16,549 & 1.37 & 15,526 & 2.00 \\
\hline to other & 1,043 & 0.09 & 705 & 0.09 \\
\hline subtotal & 86,008 & 7.11 & 74,640 & 9.60 \\
\hline \multicolumn{5}{|l|}{ Reforestation } \\
\hline from pasture & 70,732 & 5.85 & 63,160 & 8.12 \\
\hline from agriculture & 85,397 & 7.06 & 4,985 & 0.64 \\
\hline from other & 14,164 & 1.17 & 10,989 & 1.41 \\
\hline subtotal & 170,293 & 14.07 & 79,134 & 10.18 \\
\hline \multicolumn{5}{|l|}{ Land-use shifts } \\
\hline Net forest change & 84,285 & 6.97 & 4,494 & 0.58 \\
\hline Urbanization & 59,850 & 4.95 & 47,876 & 6.16 \\
\hline Total hectares & 864,233 & & 863,775 & \\
\hline \multicolumn{5}{|c|}{$\begin{array}{l}\text { *The normalized \% expresses land-cover change at the island level calculated over a } \\
\text { standard } 10 \text {-year period. Changes in hectares are calculated over a 14-year and 9-year } \\
\text { period, respectively. }\end{array}$} \\
\hline
\end{tabular}




\section{References}

Departamento de Recursos Naturales y Ambientales. 1998. Fases y técnicas utilizadas en el inventario científico de los recursos naturales.

Fagan, M. E. and R. S. DeFries. 2009. Measurement and Monitoring of the World's Forests: A Review and Summary of Technical Capability, 2009-2015. The World's Forests: Design and Implementation of Effective Measurement and Monitoring. Washington, D.C., Resources for the Future. 70 pp. 